\title{
Outsourcing Strategy of Logistical Activities as Adaptive Tool for SMEs
}

\author{
Firas Rifai ${ }^{1} \&$ Abdulrahman Hashem ${ }^{2}$ \\ ${ }^{1}$ Department of Business Administration, Faculty of Business, Al-Zaytoonah University of Jordan, Jordan \\ ${ }^{2}$ Finance and Banking Department, Faculty of Business, Isra University, Jordan \\ Correspondence: Firas Rifai, Department of Business Administration, Faculty of Business, Al-Zaytoonah \\ University of Jordan, P. O. Box 130, Amman 11733, Jordan.
}

$\begin{array}{lc}\text { Received: June 5, } 2018 & \text { Accepted: June 22, } 2018 \quad \text { Online Published: August 21, } 2018 \\ \text { doi:10.5539/jms.v8n3p88 } & \text { URL: https://doi.org/10.5539/jms.v8n3p88 }\end{array}$

\begin{abstract}
In reference to the accelerated development in the world of business, several economic concerns have been emerged such as: growing competitive pressure in the SMEs and large companies, increase in customers' demand for services, emphasis on critical operations, better customer satisfaction, globalization, etc.

To manage every one of these difficulties Logistics prerequisites have continuously expanded, for example, delivery time, Just-in-Time technique, Order cycle, Order fill rate, Order processing, enhancing project management, cost reduction and many others. In this manner, SMEs and large companies consider logistics as a potential key competitive advantage. Also, there is a growing demand for professional logistics and modified logistics solutions. The tailored complex logistics providers offer their packages under special term contract that add special values to the clients. However, some companies still have deficits and needs for proper logistical services, as they had assigned traditional logistics services, such as transport and storage services, to a specialized Logistics service provider. This article tries to give an illustration about contract logistics concept for companies.
\end{abstract}

Keywords: logistics service provider, small and medium sized enterprises, contract logistics, outsourcing

\section{Introduction}

The robust business environment leads companies to continually rebuild their strategies and aim to apply cost-cut measures in order to gain competitive advantages (Tohmatsu, 2005). Therefore, logistics service providers become high in demand to help the companies meet their needs and to effectively cut cost and achieve the requested added value (Klaus et al., 2010; Straube/Pfohl, 2008).

Outsourcing is assigning at least one business processes or functions to an outside supplier who consequently, possesses, controls and managed the assigned processes or functions according to defined and measurable performance metrics. It is an agreement in which one company contracts-out certain part of their existing internal activity to a capable logistics service provider. According to changing business environment and small size companies, which are not capable of building their own logistics department, outsourcing has become the popular solution to solve all logistics-related challenges (Ogorelc, 2007).

Some of the most significant reasons that drive companies to outsource logistical activities, are:

The demand for customized products,

Market Competition,

Customers' demand for special services (Scholz-Reiter et al., 2008),

Emphasis on critical operations (core competencies),

Reduce Back-office Operations,

Enhance Customer Satisfaction,

Reduced Liabilities,

Achieve Economies of Scale, and 
Effective Real-time Tracking. (Logistics Services, 2018)

The main question is which task to be assigned to third party logistics provider. The answer to the questions depends on the nature of the outsourcing company's business.

According to Halldorsson et al. (2004), Langley et al. (2002), McKinnon/Forster (2000), Mol (2001), and Ogorelc et al. (2002), the main requested outsourced logistics services are as follow:

1) Warehousing

2) Outbound Transportation

3) Cross-Docking / Shipment Consolidation

4) Inbound Transportation

5) Freight Bill Auditing / Payment

6) Freight Forwarding

7) Order Fulfillment and Distribution

8) Inventory Management

At the beginning of the "outsourcing strategy", logistics service providers were typically contracted in the areas of transport and warehousing. However, the increase of corporate and individual requirements caused the increase in the demand for logistics services (Scholz-Reiter et al., 2008). In the 90's, the outsourcing fashion was empowered by the companies' conviction with the concept of "focusing on core competencies" (Schwarz, 2005; Prahalad/Hamel, 1990). As a result of the continuous demand for professional logistics, contemporary logistics services continue to grow (Klaus et al., 2010).

Currently, companies are increasingly outsourcing their entire logistics to external logistics service providers (Weber et al., 2007). As a result, logistics service providers offer customized integrated logistics service packages, which are covered by the term contract logistics (Straube/Frohn, 2007).

Regarding the Small and Medium Size companies' limitation in terms of the available resources, and proper logistical ccompetencies, it is difficult for them to meet the increasing demand for logistics services (Kummer, 1992). Small and medium-sized companies have already recognized the importance of logistics outsourcing, but it is still limited to the classical transport or storage services (Gericke, 2009).

One of the most common obstacle for outsourcing contracts, especially for small and SME's companies, is the contract conditional term regarding the minimum sales volume. This conditional term may pose a major problem to most of the aforementioned companies (Klaus/Hartmann/Kille, 2010).

\section{Literature Review}

The contract logistics is counted among the logistic system service companies (Gudehus, 2007). Logistics services consist of information services, logistical core services and additional services. In turn, the core logistics services are subdivided into transport, transshipment and storage services (Isermann, 1998). In addition, logistics services can be differentiated into stationary and non-stationary value-added processes (Sucky, 2004).

Many manufacturing companies had integrated and incubated the term "logistics outsourcing" in their own operations. In order to exploit the full potential of these relationships, the client must be prepared to integrate the service provider far into their own processes and to provide them with a high level of trust (Drodofsky, 2011).

Logistical services are provided by service providers in various forms and are classified according to four criteria.

1) The range of logistics services

2) The service area in which the service provider operates

3) The amount of logistics assets

4) The number of value added services

The logistic services range from operational to strategic logistics services and this goes along with other needed value added services. In operational logistics services, only a few value added services are provided, and as a result, more value added services are offered as the range of services increases (Baumgarten et al., 2002).

These performance enhancements, such as simple assembly, consulting, IT and financial services, improve the problem-solving ability of the service provider (Pfohl/Buse, 2000; Zadek, 2004), but also links the provider with the client and make it hard to terminate the contract. Due to cost and quality advantages that are gained by a 
shipping company from contract logistics service, contract logistics is now playing a considerable role in industrialized economies (Drodofsky, 2011).

Large companies normally have the financial stability and the ability to establish their own logistics departments, however most of the SME's are considered financially weak because of the difficult access to the capital market (Bitzer, 1977). Therefore, they cannot establish their own logistics departments. Hence, SME's apply outsourcing strategy to receive different types of logistics services. In this issue we have 4 types of logistics services providers:

1) individual service provider,

2) the freight forwarder,

3) the 4th Party Logistics Provider (4 PL), and

4) the contract logistics service provider

The figure below shows the highly fragmented international logistics market with the largest logistics service providers worldwide.

\section{The global Market}

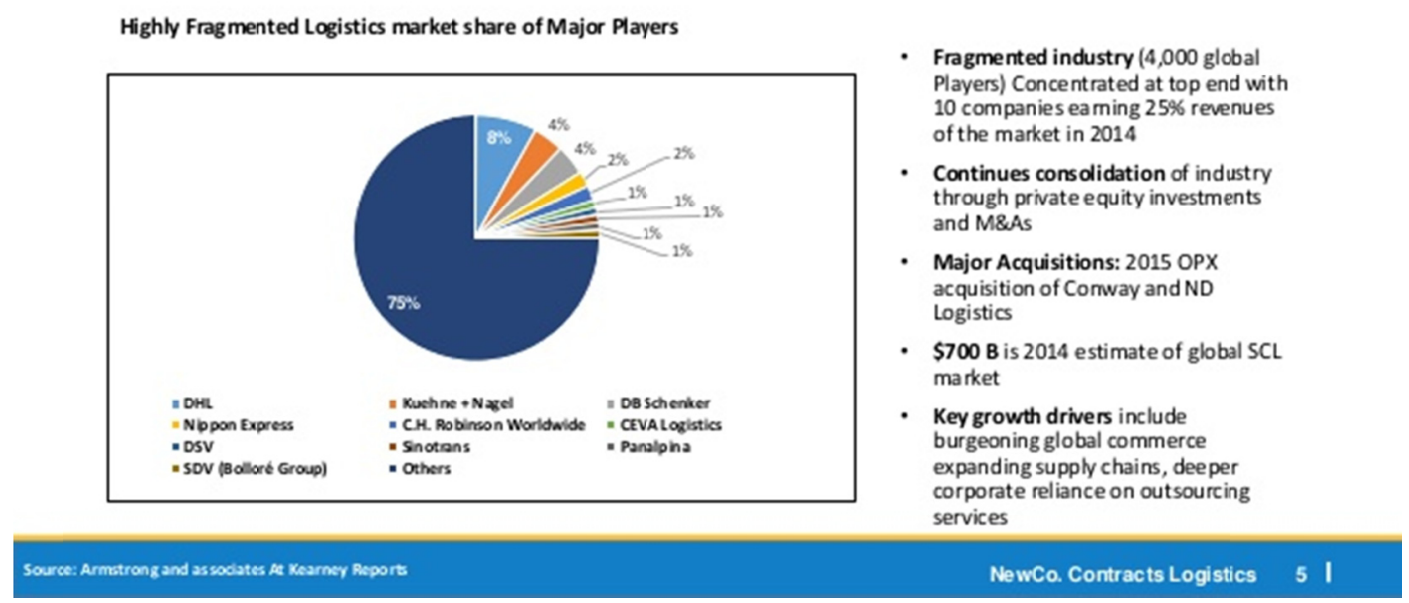

Figure 1. Highly fragmented logistics market share of major players

Source: Al-Fatayerji, 2018.

The aforementioned types shall be elaborated below in an ascending order according to the size of the added values:

For individual service providers, operational logistics services are provided to clients while only a small amount of value-added services are provided to a customer. The range of business operations can be rather limited and linked to high assets utilization, the so-called logistics assets (Haas, 2011).

The freight forwarder performs the operational and the coordination parts, which is why the freight forwarder also offers more value-added services.

4th Party Logistics Provider (4PL) offers a wide spectrum of services that includes coordination, integration of strategic logistics services, and conduct local and international operations (Haas, 2001).

Contract logistics mainly offers the full bundle of logistics services that ensures the maximum value added to their clients (Baumgarten et al., 2002) / (Gudehus, 2007). Contract logistics is designed privately and specifically for the customer to become a tailored business relationship that includes the traditional logistics services and other types of services to create an integrated service bundle (Klaus et al., 2010).

Due to the individually designed business relationship and the tailor-made logistics concepts, bilateral investments are also required from the logistics provider (Klaus/Kille, 2008). This kind of investment requires the logistics provider to adapt his assets according to the client's special needs; therefore the relationship must have a relatively longer duration in order to justify this investment. 
A specific contract period, according to Gudehus, is approximately between 3 and 10 years and could be longer in many cases (Gudehus, 2007).

Further to the long duration of the contract, another criterion of logistics contracts which concerns the volume of business. According to Klaus, contract logistics must have a minimum annual turnover (Klaus et al., 2010) which can be defined by negotiation.

The customized logistics packages also include value-added services which are defined as additional services that differentiate the logistics provider from other competitors, and consequently, the customers' benefits increase (Kille, 2008).

Frohn defined logistics value-added services as follows: "Logistic value-added services are logistical tasks tailored to clients or segments beyond basic services in the areas of transport, transshipment and warehousing, whose external provision by specialized service providers represents a net increase in value compared to internal provision by creates the client" (Frohn, 2006).

There are also two business models for contract logistics:

1- The classic single-user system:

This system is referred to as "real" contract logistics, where logistics service package is put together specifically for a customer according to individual requirements.

2- The multi-user system:

This system includes a contractual agreement with several companies in industry and trade (Waibel et al., 2007) / (Klaus, 2007). Of course, this does not prohibit logistics service providers to apply the accumulated know-how and process flows from a single user system to other customers.

In order to differentiate their services, contract logistics companies provide the following additional advantages for customers, including:

- Offer better service improvement compared to traditional logistics outsourcing.

- Conduct operational and coordination logistics services

- Finally, the customer can choose to outsource the entire processes to the logistics service provider in order to optimize the processes (Haas, 2001).

- Assist the clients to access global markets before actual market entry occurs (Kersten/Koch, 2007).

\section{Small-Medium Sized Enterprises}

The terms middle class, medium-sized enterprises and small and medium-sized enterprises (SMEs) are often used interchangeably in the literature (Damken, 2007). Medium-sized companies as well as small and medium-sized enterprises include not only medium-sized but also small enterprises. In this contribution, the terms medium-sized and medium-sized enterprises are used synonymously.

A general definition for medium-sized enterprises does not exist in the literature (Thomas, 1994). Due to the heterogeneity of the various contract logistics relationships and business content, the diverse and sometimes strongly divergent definitions of the contract logistics concept have led to conceptual ambiguity and demarcation problems (Large, 2009). However, collectively, contract logistics relationships are generally a close and deeply integrated relationship between a service provider and at least one client (Weber et al., 2007). Therefore, SMEs are delineated using quantitative and qualitative criteria (Thomas, 1994) such as "unity of ownership and leadership" (Damken, 2007), "Manageability of the organizational structure" (Kosmider, 1994).

Generally, in small and medium-sized companies, ownership and leadership are mainly united in one person (Damken, 2007). The particularity of corporate governance is based on the fact that entrepreneur exerts elementary influence and shapes the corporate culture, when decisions are made concerning company policy (Stephan 2002).

Despite of the need and the importance of logistics, many SMEs do not implement general logistics concepts. In large companies, there is usually an institutionalized department for the logistics sector. After all, the focus in the SMEs sector is on the implementation of operational logistics services; in large companies, strategic logistics services are also carried out (Pfohl, 2006a) \& (2006b).

The partnership between the provider and the client is not limited to the classical shape of a normal business relationship. This relationship could exceed the classical limits through trust, honesty, and shared contract's objectives (Lambert et al., 1999). 
Due to the conditions in SMEs, the increasing demands on logistics services can be difficult to meet. One possible solution to this issue is the outsourcing of logistics to a specialized service provider. Moreover, due to the structure of SMEs, certain concerns about service quality may prevent implementing logistics outsourcing, as quality is heavily linked to company's reputation and sustainability (Gericke, 2009). Generally, the outsourcing decision is made on the grounds of clear performance shortcomings or high costs (Gebhardt, 2005).

\section{Problems Between Contract Logistics and SMEs}

Contract logistics represents a possibility to fill into the gaps of logistics services in SMEs operations. However, looking more closely at SMEs and contract logistics, it can be said that there are compatibility issues that will be identified and demonstrated below.

Due to the investments that the contract logistics service provider has to make for the customer-specific logistics needs, contract logistics transactions generally require a longer-term duration (Gudehus, 2007). However, SMEs are rather skeptical of cooperation Buse (1997), because of the lengthy required relationship.

A criterion of contract logistics is according to Klaus a substantial minimum turnover in the Year. In industrial countries for example a minimum turnover of between 0.5 and 1 million Euros per year is considered practical (Klaus et al., 2010). This is certainly different in other countries and depends on the strength or weakness of the economy in general. Therefore for the application of contract logistics services the requirement of minimum turnover volume must be defined by negotiation. The investment amount which the provider allocated in order to offer the customized logistics solutions, affect directly the definition of the turnover volume (Gudehus, 2007).

However, these investments only pay off for the contract logistics provider after a certain minimum turnover and a certain contract period. For example, if the contract is not renewed by the customer, the question arises for the contract logistics provider of the extent to which the logistics assets can continue to be used due to their specificity (Haas, 2001).

In recent years, growth rates have always been higher than in other logistics market segments. However, despite this positive market development, the fragility of these relationships should not be ignored (Drodofsky, 2011). Wilding and Juriado reached to a conclusion through their study showing that $74 \%$ of contracting companies have not renewed a contract logistics contract at least once (Wilding/Juriado, 2004). In addition, there are premature terminations of contracts, for example due to the bankruptcy of a contracting party or premature, extraordinary dismissals.

The termination of a relationship between the two parties is one of the basic subjects of relationship management, in addition to the already intensively researched business development and the management of an ongoing relationship (Halinen/Tähtinen, 2002).

The termination of contract logistics relationships has been marked as a field of further research due to the ambiguity of it. There should be a clearer understanding to frame the ending of a professional relationship between the provider and the clients (Arnold, 2007). The nature, reasons and process of "contract termination" is very important, but it will not be discussed further here.

\section{Conclusions and Recommendations}

Changing environment is adding increase pressure on the SMEs and large companies, to respond to the ever-ending customer needs. The logistic providers are in constant struggle to attract new clients, therefore their abilities to provide customized logistics solutions to them is challenged by the changing needs.

The utilization of the offered services can help SMEs to reduce pressure and to provide value added services to their clients. Their un-strong financial positions, sometimes do not allow them to create their own logistics departments. Therefore, dealing with third-party logistics provider, is considered a way-out.

Nevertheless, dealing with third-party logistics provider, is attached to many risks and special conditions which can be considered as unsolvable obstacles. There are few indicators that companies take into their consideration during negotiating the terms contract between each party.

For the development of the "contract logistics" concept, empirical investigations are mostly needed. Further research is required on the factors that affect the logistics contract including the conditions, indicators, termination, duration, etc. 


\section{References}

Al-Fatayerji, H. (2018). NewCo.Contract Logistics. Investment Proposal. Retreived from https://www.slideshare.net/HashimAlFatayerji/new-co-contract-logistics

Arnold, U. (2007). Beendigung von Lieferantenbeziehungen in Unternehmensnetzwerken. In F. J. Garcia Sanz, K. Semmler, \& J. Walther (Hrsg.), Die Automobilindustrie auf dem Weg zur globalen Netzwerkkompetenz. Berlin. https://doi.org/10.1007/978-3-540-70787-5_12

Baumgarten, H., Kasiske, F., \& Zadek, H. (2002). Logistik-Dienstleister-Quo vadis?—Stellenwert der Fourth Logistics Provider (4PL). Logistikmanagement, 4(1), 27-40.

Bitzer, K. (1977). Der mittelständische Unternehmer — einige betriebssoziologische Aspekte, Berlin.

Buse, H. P. (1997). Kooperationen. In H. C. Pfohl (Hrsg.), Betriebswirtschaftslehre der Mittel-und Kleinbetriebe -Größenspezifische Probleme und Möglichkeiten zu ihrer Lösung, 3. Aufl., Berlin.

Damken, N. (2007). Corporate Governance in mittelständischen Kapitalgesellschaften-Bedeutung der Business Judgement Rule und der D\&O-Versicherung für Manager im Mittelstand nach der Novellierung des $\$ 93$ $A k t G$ durch das $U M A G$, Edewescht.

Deloitte Touche Tohmatsu. (2005). Core competences and strategic outsourcing: Achieving competitive advantage.

Drodofsky, M. (2011). Dienstleisterperspektiven. In Logistikmanagement: Herausforderungen, Chancen und Lösungen Band. Logistik und Supply Chain Management.

Frohn, J. (2006). Mehrwertleistungen in der Kontraktlogistik, Aachen.

Gebhardt, A. (2005). Fremdgehen lohnt sich. In Logistik heute, Heft 6, pp. 46-47.

Gericke, J. (2009). Unterstützung von Logistik-Outsourcing Entscheidungen in mittelständisch strukturierten Unternehmen, 2. Aufl., Taunusstein.

Gudehus, T. (2007). Logistik 2-Netzwerke, Systeme und Lieferketten, 3. Aufl., Berlin Heidelberg.

Haas, S. (2011). Kontraktlogistik für mittelständische Unternehmen, Lehrstuhl für Produktion und Logistik. Otto-Friedrich-Universität Bamberg.

Halinen, A., \& Tähtinen, J. (2002). A process theory of relationship ending. Journal of Service Industry Management, 13(2), 163-180. https://doi.org/10.1108/09564230210425359

Halldorsson, A., \& Skjott-Larsen, T. (2004). Developing logistics competences through third party logistics relationships. International Journal of Operations \& Production Management, 24(2), 192-206. https://doi.org/10.1108/01443570410514885

Isermann, H. (1998). Grundlagen eines systemorientierten Logistikmanagements. In H. Isermann (Hrsg), Logistik—Gestaltung von Logistiksystemen, 2. Aufl., Landsberg/Lech.

Kersten, W., \& Koch, J. (2007). Motive für das Outsourcing komplexer Logistikdientleistungen. In W. Stölzle, J. Weber, E. Hofmann, \& C. M. Wallenburg (Hrsg.), Handbuch Kontraktlogistik—Management komplexer Logistikdienstleistungen, Weinheim.

Kille, Ch. (2008). KEP-Märkte und Dienste. In P. Klaus \& W. Krieger (Hrsg.), Gabler-Lexikon Logistik: Management logistischer Netzwerke und Flüsse, 4. Aufl., Wiesbaden.

Klaus, P. (2007). Markt für Kontraktlogistik. Volumen und Entwicklungen in Europa. In W. Stölzle, J. Weber, E. Hofmann, \& C. M. Wallenburg (Hrsg.), Handbuch Kontraktlogistik-Management komplexer Logistikdienstleistungen, Weinheim.

Klaus, P., \& Kille, Ch. (2008). Kontraktlogistik. In P. Klaus \& W. Krieger (Hrsg.), Gabler-Lexikon Logistik: Management logistischer Netzwerke und Flüsse, 4. Aufl., Wiesbaden.

Klaus, P., Hartmann, E., \& Kille, Ch. (2010). Top 100 der Logistik-Marktgrößen, Marktsegmente und Marktführer in der Logistikdienstleistungswirtschaft, Hamburg.

Kosmider, A. (1994). Controlling im Mittelstand-Eine Untersuchung der Gestaltung und Anwendung des Controllings in mittelständischen Industrieunternehmen, 2. Aufl., Stuttgart.

Kummer, S. (1992). Logistik im Mittelstand-Stand und Kontextfaktoren der Logistik in mittelständischen Unternehmen, Stuttgart. 
Lambert, D. M., Emmelhainz, M. A., \& Gardner, J. T. (1999). Building successful logistics partnerships. Journal of Business Logistics, 20(1), 165-181.

Langley, C., John, A., Gary, R., \& Tyndall, G. R. (2002). Third-Party Logistics Study, Results and Findings of the 2002 Seventh Annual Study.

Large, R. (2009). Steuerung in Kontraktlogistikbeziehungen. Controlling, 21(8/9), 444-449. https://doi.org/10.15358/0935-0381-2009-8-9-446

Logistics Services. (2018). 8 Reasons to outsource Logistics services. Retrieved from https://www.flatworldsolutions.com/logistics/articles/outsource-logistics-services-8-reasons.php

McKinnon, A., \& Forster, M. (2000). European Logistical and Supply Chain Trends: 1999-2005. TRILOGEurope: a project of Directorate-General VII (Transport) of the European Commission undertaken in support of the Organisation for Economic Co-operation and Development's (OECD) Trilateral Logistics study.

Mol, M. J. (2001). Outsourcing, Supplier Relations and Internationalization: Global Sourcing Strategy as a Chinese Puzzle. Rotterdam School of Management, Erasmus University Rotterdam.

Ogorelc, A. (2007). Outsourcing of Transportation and Logistics services.

Ogorelc, A., \& Zelenika, R. (2002). Towards Outsourcing of Logistics Activities in Manufacturing Firms. In M. David (ur.), ICTS 2001: Proceedings. Portoroz: Fakulteta za pomorstvo in promet.

Pfohl, H.-C., \& Buse, H. P. (2000). Inter-organizational logistics systems in flexible production networks. International Journal of Physical Distribution \& Logistics Management, 30(5), 388-408. https://doi.org/10.1108/09600030010336153

Pfohl, H.-Ch. (2006a). Betriebswirtschaftliche Funktionen: Logistik. In H. C. Pfohl (Hrsg.), Betriebswirtschaftslehre der Mittel—und Kleinbetriebe—Größenspezifische Probleme und Möglichkeiten zu ihrer Lösung, 4. Aufl., Berlin.

Pfohl, H.-Ch. (2006b). Grundlagen-Abgrenzung der Klein- und Mittelbetriebe von Großbetrieben. In H. C. Pfohl (Hrsg.), Betriebswirtschaftslehre der Mittel- und Kleinbetriebe-Größenspezifische Probleme und Möglichkeiten zu Ihrer Lösung, 4. Aufl., Berlin.

Prahalad, C. K., \& Hamel, G. (1990). The Core Competency of the Corporation. Harvard Business Review, May-June, 79-91.

Scholz-Reiter, B., Toonen, Ch., \& Windt, K. (2008). Logistikdienstleistungen. In D. Arnold, H. Isermann, A. Kuhn, H. Tempelmeier, \& K. Furmans (Hrsg.), Handbuch Logistik, 3. Aufl., Heidelberg.

Schwarz, G. (2005). Outsourcing—Eine Einführung. In H. J. Hermes \& G. Schwarz (Hrsg.), Outsourcing, Freiburg im Breisgau.

Stephan, P. (2002). Nachfolge in mittelständischen Familienunternehmen-Handlungsempfehlungen aus Sicht der Unternehmensführung, Wiesbaden.

Straube, F., \& Frohn, J. (2007). Kundennutzen durch logistische Mehrwertleistungen. In W. Stölzle, J. Weber, E. Hofmann, \& C. M. Wallenburg (Hrsg.), Handbuch Kontraktlogistik-Management komplexer Logistikdienstleistungen, Weinheim.

Sucky, E. (2004). Koordination in Supply Chains-Spieltheoretische Ansätze zur Ermittlung integrierter Bestell—und Produktionspolitiken, Wiesbaden.

Thomas, K. G. (1994). Die mittelständische Unternehmung im Entwicklungsprozess, Berlin.

Waibel, F., Herr, S., \& Schmidt, N. (2007). Ramp up in der Kontraktlogistik, Stuttgart.

Weber, J., Stölzle, W., Wallenburg, C. M., \& Hofmann, E. (2007). Einführung in das Management der Kontraktlogistik. In W. Stölzle, J. Weber, E. Hofmann, \& C. M. Wallenburg (Hrsg.), Handbuch Kontraktlogistik—Management komplexer Logistikdienstleistungen, Weinheim.

Wilding, R., \& Juriado, R. (2004). Customer perceptions on logistics outsourcing in the European consumer goods industry. International Journal of Physical Distribution \& Logistics Management, 34(8), 628-644. https://doi.org/10.1108/09600030410557767 
Zadek, H. (2004). Struktur des Logistik-Dienstleistungsmarktes. In H. Baumgarten, I. Darkow, \& H. Zadek (Hrsg.), Supply Chain Steuerung und Services: Logistik-Dienstleister managen globale Netzwerke (pp. 15-28). Best practices, Berlin, Heidelberg. https://doi.org/10.1007/978-3-662-10148-3_2

\section{Copyrights}

Copyright for this article is retained by the author, with first publication rights granted to the journal.

This is an open-access article distributed under the terms and conditions of the Creative Commons Attribution license (http://creativecommons.org/licenses/by/4.0/). 